\title{
ICT as a Re-Engineering Strategy on Claim Settlement in Some Selected Insurance Companies In Nigeria: The Pandemic Experience
}

\author{
Madu Frances ${ }^{1}$, Isichei Ejikeme², Vincent Onodugo ${ }^{1}$. \\ ${ }^{1}$ University of Nigeria, Enugu Campus, faculty of Business Administration, Enugu State, Nigeria. \\ ${ }^{2}$ Federal University Wukari, Faculty of Humanities and Management Sciences, Taraba State, Nigeria.
}

\begin{tabular}{l}
\hline ARTICLE INFO \\
\hline Article History \\
Received 28 May 2021 \\
Accepted 10 November \\
2021 \\
\hline JEL Classifications
\end{tabular}

D83, G22, G52

Keywords:

Coronavirus (COVID-19), Information

Communication Technology (ICT), Insurance, Reengineering, Strategy.

\section{ABSTRACT}

Purpose:

This study addresses the effect of ICT on the relationship between re-engineering and the performance of some selected insurance companies in Nigeria. It emphasizes the need to ensure that insurance companies achieve substantial improvement in performance via viable IT infrastructure to modernize all business processes.

Design/Methodology/Approach:

The study adopted a survey design, utilizing a sample of 350 respondents from two selected insurance companies in the southwest geopolitical zone of Nigeria. A questionnaire was used for the collection of data. The data analysis was conducted using the percentage formula and SPSS version 20.

Findings:

The research revealed that there is a significant relationship between ICT and operational performance of the insurance companies, the increase in the use of many ICT tools has proven to be caused by lockdown, which implies insurance companies should endeavor to provide updated ICT facilities to enable good quality service delivery and profitability. Technological innovations through ICT enabled the insurance industry to set up efficient delivery channels, which has capacitated the sector to solve the problems that are posed by the new change. ICT tools aided supervisors, employees, and managers in decision-making. Operational resilience became the proactive measure made by the insurance sector to ensure responsive, adaptable, and scalable services for the insured and stakeholders.

Research limitation/Implication:

This study exhibits practical implications for the financial service provider, as the manager and the insurer (Insurance companies) can be encouraged to find the best approach to redesign strategies and adopt basic IT facilities to automate business activities for optimal productivity and profitability. Coronavirus epidemic has created the need to emphasize the importance of making provision for a viable digital infrastructure, which ensures business continuity and customer retention, and there should be a collaboration between the financial service providers and implementing alternative delivery channels to achieve a thorough transformation that will strengthen the insurance sectors.

Originality/value:

This study furthers strengthens and validates the use of technology and the relevance of reengineering in operational re-enforcement for increased efficiency and effectiveness of insurance services. The improvement in business process re-engineering is driven by ICT, and as a re-engineering enabler, enhances performance that could lead to competitive advantage and a great priority for insurance companies to gain more control over the final market and good customer relationship, by offering quality services, superior value to the services, affordable price, unique customization and consultation 


\section{Introduction}

The outbreak and the spread of the coronavirus disease (COVID-19) in Africa have caused severe infection and high rates of death. An estimate from Africa Centre for disease control and prevention revealed as of 7 th July 2020 , a total of 492,624 COVID-19 cases and 11,622 (CFR: 2.4\%) deaths from 54 African countries, which is $4.3 \%$ of all cases worldwide, (Africa CDC, 2020). South Africa (224,665), Egypt (78,304), Nigeria (30,249), Ghana (22,822), and Algeria $(17,348)$ have the most cases as of $9^{\text {th }}$ July 2020 (ECDC, 2020). The virus has caused a surge in health, business interruptions, and cancellation of travels, thus increasing the number of claims. A claim is the payment made by the insurance company to the insured, policyholder, or claimant on the occurrence of the event stated in the contract, in return for the premiums paid for the insured. As the number of inquiries and claims increases, the major objective of insurance companies becomes to provide peace of mind in times of crisis and stress. To offer prompt claims settlement during the pandemic, the insurance companies may need to initiate strategies for managing the crisis from the customers' and stakeholders' perspectives. The environmental change due to the pandemic and customers' demand for products and services have made the insurance sector seek technological solutions to solve the problem the change presents. The technological changes have impacted greatly on the employees, insured, and management, and the advancement in technology may enable the industry to deliver quality and efficient insurance products and services.

In the financial sector, the insurance industry has experienced rapid growth with the advancement in the level of information technology. It has brought a dramatic breakthrough in performance, called "REENGINEERING". Hammer and Stanton (1995), defined re-engineering 'as the fundamental rethinking and radical redesigning of business processes to bring about dramatic performance improvement. Business process reengineering centers on those approaches that redesign individual internal systems and respond to external forces to achieve sophisticated objectives (Asgarkhani \& Patterson, 2012). This is restructuring or repositioning of the insurance operations, by developing advanced information and communication technology, efficient human resources management, strategic planning, good customer service management, prompt service delivery, and claim settlement bring about significant changes. Sungau et al., (2013) posit that change must occur in a service organization to provide quality services to customers without time-wasting. In this vein, Hammer \& Champy(1993), Broersma (1997), Hesson (2007), Banham 2010) supported that Customers' demand and technology have contributed to the frequent changes experienced in the organization A change to introduce new ICT technologies that will enhance and strengthen the internal and external operations of insurance businesses regardless of the clients' location. Prompt underwriting services, speedy claim settlement, and effective customer service are the major areas where the use of ICT might play a major role to limit delays, increase the efficacy and enhance operational excellence. The aim of the study is to assess and evaluate the degree to which these aspect of ICT as a re-engineering strategy has affected the business operations of the insurance companies during the corona virus pandemic.

Business process re-engineering has gained increased circulation, over the past years, and enabling role of ICT has become an important factor for implementing business process re-engineering. BPR application became possible for the business upgrade, with the help of technology, employees can operate as a team using intranet and extranets, and increasing workflows which eliminate distances. The aim of working together regardless of distance and location is achieved. The computerized process is to improve quality, avoid time-wasting in processing, share a database, making information available at many places at the same time, allowing the organization to be centralized and decentralized to aid decision making (Mohapatra, 2013). Several studies have provided varying evidence on the relationship between ICT as a re-engineering strategy and the performance of insurance firms in Nigeria and the world. Apampa \& Olatunji (2010), Augustine (2017), Kimani (2017) have identified positive relationships and justified the ICT usage in Nigeria. This justifies the view of Bazini \& Madani (2015) that there are interrelated factors that are likely influencing the insurance companies' performance. Therefore the need for assessing the interrelationship with other variables is supported to further clarify their relationship. However, reengineering in most of the world has been considered the most appropriate in today's business environment. There is a paucity of studies that have assessed the role of ICT on the relationship between re-engineering and the performance of the organization in a developing economy such as Nigeria. The study tends to close this gap. Nevertheless, there is limited knowledge on how re-engineering strategies evolved and their contributions to organizational performance. With this more time, processes, and resource investment are needed, which cannot be provided by most insurance companies in developing countries.

\section{Objectives of the Study}

The main objective of the study was to evaluate the role of ICT as a re-engineering strategy in some selected insurance companies. The specific objectives were to:

To assess the relationship between ICT as a re-engineering strategy and the efficiency in claim settlement of some selected insurance companies. 
To determine the effect of ICT on the preparation of policy documents as a re-engineering strategy in some selected insurance companies.

\section{Research Questions}

In line with the objectives of the study, the following research questions were formulated.

Is there a significant relationship between ICT as a re-engineering strategy and efficiency in the claim settlement of insurance companies?

Does ICT as a re-engineering strategy relate positively to the timely preparation of policy documents?

\section{Research Hypotheses}

The alternate hypotheses were formulated

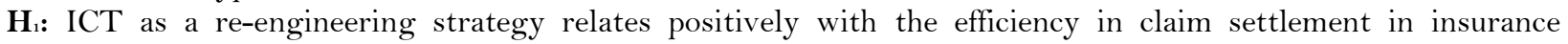
companies

$\mathbf{H}_{2}$ : ICT as a re-engineering strategy relates positively with the timely preparation of policy documents in insurance firms.

\section{Review of Literature}

Recently, the pandemic has led to increased use of technology and it has become essential in every aspect of insurance operation. Being a customer-oriented business, data, or information are collected, processed, stored, and distributed. This has given the insurance industry the drive to embrace emerging technologies, in managing client information, identifying needs and risks, and assisting in the handling of claims. The automation of the insurance business is conducted spending lesser time compared to when the conventional method is applied. Despite all these new potentials and opportunities, there are significant challenges and possible threats faced in the insurance industry. Delayed preparation of policy documents, delayed claim settlement, and error in premium calculation, delay in printing and distribution of customers' statements, unsustainable IT, high cost of establishment, lack of skilled manpower, unreliable power supply, and insecurity. Due to the competitive nature of the business environment, customers' expectations cannot be overemphasized, as getting good quality and prompt services have become their priority, and insurance companies must live up to these expectations, by facing up to competition, if they must survive. Companies can lose the market, due to poor quality services. The use of IT has been relatively ad hoc, and not being able to establish, maintain, and sustain ICT-supported programs could affect the company's performance and existence.

The question now is "what are the effects of the introduction of IT on these problems mentioned and consequently on the management of insurance. In line with the objectives of the study, the aforementioned research questions were formulated.

Recently, the insurance business has been perceived as a crucial business service that creates and adds value, as it facilitates every business by managing the risks, regardless of the enormity of the disaster or catastrophe caused by the pandemic. Insurance focuses on the reduction of the financial obligation incurred from any disaster, thus providing security to the policyholder, and also encourages people to engage in commercial activities with peace of mind, regardless of the degree of uncertainty. The insurance industry is now capable to perform more than it is currently doing, this is due to business process re-engineering which has made most companies achieve the desired optimum level of performance. This has been achieved by re-appraising and reviewing the processes of the organizational system by becoming more effective and efficient in delivering value to the stakeholders. Insurance as a service-oriented industry and also a contract between two parties involves the physical inspection of properties and filling of proposal forms. Having so many lockdown protocols and social distancing to observe, the insurance sector has to employ an organized integrated framework for automating processes to control information productions using the computer, telecommunication devices, software, and other communication gadgets to improve the efficiency of daily operational activities to achieve strategic goals.

\subsection{Theoretical and Hypothesis development}

Information and communication technology plays an enabling role in the improvement of the BPR activity cycle, by making provision for some compliments that enhance performance, thus bringing competition into the system, (Susanto et al., 2019). The aim of ICT on re-engineering in an organization is to enhance improvement towards raising the efficiency and effectiveness of the processes used within the organization, and organization must take into consideration all their operations in determining how these processes could be improved to bring out the best in the operations of the organizations. Business process re-engineering has gained increased circulation, over the past years, and the enabling role of ICT has become an important factor for implementing business process reengineering. In running the daily business activities in both public and private organizations, Information and communication technology has been a vital keystone in every aspect of human organization, which without these facets of technology all cleared works, and the daily routine task will be inoperative. 
The system by which businesses are created by the usage of ICT as an extensional term of information technology emphasizes the combination of these gadgets, telephone lines, and wireless signal, computers software, hardware, storage, and other systems that enable users to have access, to store, transmit and manipulate information. Gathering and analyzing facts aided by information and communication technologies have made communication and data easily accessible. Information and communication technologies are those adequate communication gadgets used in gathering and analyzing facts like telephone, televisions, radio, computers amongst others. The ways by which businesses are being reinforced through gathering and analyzing information, developing strategic vision, and finding the best approach for redesigning and enhancing joint teamwork, are been reshaped by these technologies. Organizations are aided by IT infrastructure, to automate business activities, and to reshape and redesign business processes (Venkatraman, 1994, Akhavan, 2006).

To improve the efficiency of the company's services, attract more profits, reduce cost, and improve turnaround time, most organizations redesign their bursary process and activities to remain relevant in the market. This is referred to as Business Process re-engineering and it is the basal assessment and radical modification of business processes to bring substantial performance improvement (Hammer \& Stanton, 1995). In today's business environment, many organizations undergo some processes, imitating designs to decrease the cost of production, reduce time, and increase the efficiency and effectiveness of some specific functions. Achieving a substantial improvement in every organization cannot be overemphasized towards achieving great success, and information technology has become an important tool in enabling business process re-engineering activity in the organization, by spicing up business operations, reducing complexity, and also having significant improvement in the company's performance and this performance can lead to competitive advantage, (Susanto et al., 2019). BPR is also a modification of the business process and unconstrained modernization of all business processes.

\subsection{Relationship between ICT and insurance firm's efficiency in claim settlement}

There have been differences in opinion regarding the application of ICT in some selected insurance companies. Yusuf et al., (2017) conducted a study on the investigation of insurance claims management among selected insurance companies in Lagos metropolis, Nigeria. The study employed a descriptive survey design using a random sampling technique and thus gathered data through the use of a structured questionnaire. The sample population consisted of 127 respondents made up of claims managers and other members of staff within the surveyed companies. One sample T-test was adopted in the analysis of collected data. The findings from the study confirmed the significance of the various claims handling processing in claims management of insurance companies in Nigeria and these claims handling processing have significant effects on the claims management processes of insurance companies. It, therefore, recommends that claims managers should put forward strategic plans to ensure that insurance claims complaint files are properly kept, monitored, and handled for needs that may warrant their usefulness in the future.

However, recent findings have justified the assessment of ICT in insurance firms. Mukhopadhyay et al., 2013) researched the improvement of claim processing cycle time through lean six sigma methodology. The objective of the study was to present a Lean Six Sigma case study for reducing cycle time in the claim settlement process in insurance services. The study presented an application of Lean Six Sigma Methodology for claim settlement cycle time reduction in the insurance sector. In their Findings, Data have been collected for 84 claimants on processing time for each step. Mixing statistical and analytical techniques helps to improve the processing speed and is very well demonstrated by the Lean Six Sigma approach for service organizations. To identify the waste generated in various processes, one needs to delineate the process in detail and find out whether the steps add value or not, to monitor claim, the overall claim settlement process, a claim pendency calculator (CPC) has been developed in MS-excel for monitoring and ascertaining the claim status by the head office.

Angima and Mwangi, 2017) stated through their research that it has become imperative as ICT today contributes to the underwriting and claims management on the performance of property and casualty insurance companies in East Africa. The study investigated the effect of underwriting and claims management practices on the performance of general insurance firms in East Africa. The study employed multiple linear regression analysis using primary and secondary data collected from 82 general insurers in Kenya, Uganda, and Tanzania. The findings show that there is a significant positive relationship between underwriting and claims management practices employed by the firms and non-financial performance, but the relationship with financial performance was insignificant. The implication is that a profit-oriented insurance firm should embrace the function of a claim that is closely related to the underwriting and pricing of the firm's portfolio for meaningful results. It is recommended that general insurance companies focus on other important factors besides underwriting and claims management to improve overall financial performance. Thus we propose that:

$\boldsymbol{H}_{1}$ : ICT as a re-engineering strategy relates positively with the efficiency in claim settlement in insurance companies 
2.3 Relationship between ICT as a re-engineering strategy and timely preparation of policy documents in the insurance firms.

It has been observed that ICT is a critical element in the drive for improved performance in the organization, and automated activity is vital to driving sustained improvement when the right facility is provided. Augustine (2017) investigated Information and Communication Technology (ICT), a catalyst for effective operation: the case of Nigerian insurance companies. He held that the emergence of Information and Communication Technology (ICT) has not only influenced our lives style and societal norms in Nigeria but has also created a new terrain for business advancement and success in the country. This study borders on the adoption of ICT into the business operations of insurance companies in Nigeria, to determine the impact of the adoption on product innovations (PI); business operations (BO); and customer satisfaction of the industry. The study adopts survey research methodology and extracted data from a primary source through well-structured designed questionnaires, using correlation and linear regression analysis to examine the present and future relationship between the independent variable (ICT) and the set of dependent variables (PI; BO; and CUST). The findings revealed that the adoption of ICT immense has a positive significant impact on PI, BO, and CUST within the insurance companies' operations if other factors are kept controlled efficiently.

The method the work system applies in an organization is designed to drive employees' innovativeness and creativity and encourages the organization to effectively take advantage of its skilled employees to leverage its available resources to achieve great results. Fadun (2013), conducted a study on the impact of Information and Communication Technology (ICT) on insurance companies' profitability in Nigeria. The study identifies the imperatives for the adoption of ICT to promote efficient service delivery in the insurance industry as a strategy for the attainment of the profit maximization objectives of insurance companies in Nigeria. The study is an empirical design that utilizes responses to the structured questionnaire of 152 respondents from 18 insurance companies to explore the impact of ICT adoption on the quality of service delivery and profitability of insurance companies in Nigeria. The study concludes that there is a positive relationship between ICT adoption and insurance companies' profitability in Nigeria. This implies that the adoption of ICT by insurance companies can enhance their efficiency, quality of service delivery, and their profitability. The findings for practice imply that insurance companies should endeavor to update their ICT facilities regularly, given its impacts on quality of service delivery and profitability. The paper also highlights the need for regular training of insurance personnel to keep them abreast of the current innovations in the use of ICT to ensure that the industry contributes positively to the economy.

Given this Kimani (2017) carried out a study on the effect of Information and Communication Technology (ICT) strategy implementation on customer service delivery in the insurance industry in Kenya. The study used a descriptive research design. The target population of the study consisted of individual policyholders with active policies in the top 10 insurance companies in Kenya. The list of the top 10 insurance companies was obtained from the Insurance Regulatory Authority (IRA). A list of the active policyholders was obtained from the respective insurance companies. The sampling technique for this study was a stratified random sampling technique. Questionnaires were used to collect data from the selected respondents. The study concludes that customers understood customer service delivery that was offered by the insurance industry and the rating of customer service delivery by the insurance providers in Kenya was high. From the study, it can be concluded that customers were familiar with the automated online insurance application processes and the usability of the online underwriting process was highly better than the manual process. Hence we propose that:

$\boldsymbol{H}_{s:}$ ICT as a re-engineering strategy relates positively with the timely preparation of policy documents in insurance firms.

\section{Methodology}

The design adopted for the study was a survey research design. Primary and secondary data were used for the study. A structured questionnaire was also used to generate responses from members of staff. The population of the study consist of all senior and junior staff of these selected insurance companies. The population of IGI PLC and Leadway Assurance staff was 2830. The study adopted the Freund and William statistical formula in calculating the sample size which is 350. Two evaluators from the University of Nigeria Nsukka, and Enugu State University of Science and Technology respectively, validated the questionnaire instrument. In testing the reliability of the questionnaire, test re-test methods were employed, by administering 15 copies of the questionnaires to similar respondents, and was re-administered to the same respondents after two weeks, two sets of responses obtained correlation using the Pearson product-moment correlation $(\mathrm{r})$ and a coefficient of reliability of 0.95 was obtained, which is above the threshold of 0.70 (Hair et al., 2010). This evidence shows that the instrument is reliable for data collection. Five research assistants were employed to distribute and collate the questionnaires. Pearson product-moment correlation technique was used for analysis with the aid of SPSS version 20. The study chose Lagos state as the area of study since the headquarters of the aforementioned insurance companies are situated there. Lagos state is located in the southwest geopolitical zone of Nigeria. The choice of the state was guided by the fact that most re-engineering activities occur at head offices. The author could not visit

DOI: $10.25103 /$ ijbesar.143.06 
these insurance companies, because the movement was restricted in some parts of the country, but a soft copy was sent to the contacts, who printed out and distributed the questionnaires to the staff working in marketing, account, underwriting, claims, and ICT departments. The study was conducted in July - September 2020, shortly after the lifting of the lockdown.

\section{Result and Discussion}

The usable questionnaires gathered were three hundred and fifty (350) of the three hundred and eighty-five retrieved. The researchers dropped the thirty-five questionnaires because they had varying issues such as mutilation, missing responses on some major items and double ticking in some cases. Common method variance was assessed using factor analysis and it was found that none of the variables accounted for more than $50 \%$, which indicates the absence of bias. Chi-square for the difference was assessed given the difference in the time frame the data was received and because some of the instrument was not retrieved. The result indicates that there is no significant difference.

Sequel to this, the three hundred and fifty (350) instrument was used for further analysis. The demographic distribution of the instrument shows that $200(57.1 \%)$ are male, while $150(42.9 \%)$ are female respondents that took part in the survey. The instrument also shows the age distribution of the respondent to be 18-30 are 90, which is $25.71 \%$ of the respondents, 31-40years are 172 , which is $49.14 \%$ of the respondents, $41-50 y e a r s$ are 51 , which is $14.57 \%$ of the respondents, and 50years and above are 37 , which is $10.57 \%$ of the respondents.

Table 1: Educational level of the employees

\begin{tabular}{|c|c|c|}
\hline $\begin{array}{l}\text { The educational level } \\
\text { employees }\end{array}$ & Frequency & Percent \\
\hline WASC/SSCE and below & 2 & 0.57 \\
\hline$N C E / O N D$ & 16 & 4.57 \\
\hline$H N D / B S c$ & 250 & 71.43 \\
\hline Master degree and above & 74 & 21.14 \\
\hline Other specify & 8 & 2.29 \\
\hline Total & 350 & 100 \\
\hline
\end{tabular}

Source: Field survey, 2020

Table 2, shows that the majority of the respondents are graduates of higher institutions, which shows that the respondents are educated enough to fill the questionnaires.

Table 2 Designation and grade

\begin{tabular}{l|c|c|}
\multicolumn{1}{c}{ Option } & Frequency & Percent \\
\hline Top Management & 40 & 11.43 \\
\hline Middle Management & 250 & 71.43 \\
\hline Lower Management & 60 & 17.14 \\
\hline Total & 350 & 100
\end{tabular}

Source: Field survey, 2020

The field experience shows that the largest number of respondents is in the middle management cadre with $71.43 \%$ respondents from the category.

Table 3 Respondent department/section

\begin{tabular}{l|c|c|} 
Department & Frequency & Percent \\
\hline Underwriting & 60 & 17.14 \\
\hline Claims & 43 & 12.29 \\
\hline Marketing & 130 & 37.14 \\
\hline Account & 65 & 18.57 \\
\hline Other specify & 52 & 12.86 \\
\hline Total & 350 & 100
\end{tabular}

Source, Field survey, 2020

The data from the above table 3 shows that a large number are from the marketing department follows by the underwriting and accounts department and the small numbers are from claims and other departments such as the administrative and ICT. 
Table 4: Descriptive Statistics on ICT as a re-engineering strategy in insurance firms in Nigeria

\begin{tabular}{|l|c|c|c|}
\hline & Mean & Std. Deviation & N \\
\hline ICT & 4.0114 & .87295 & 350 \\
\hline policy document preparation & 3.9486 & .87151 & 350 \\
\hline Claim settlement & 4.0771 & .79561 & 350 \\
\hline
\end{tabular}

Source: Fieldwork, 2020

The descriptive means and standard deviation of the variable shows a good mean response for each of the study variables. This indicates that responses to the variables are sufficient for further analysis.

\begin{tabular}{|c|c|c|c|c|}
\hline \multicolumn{5}{|c|}{ Table 5: Correlations result on ICT as a re-engineering strategy in insurance firms in Nigeria } \\
\hline & & ICT & $\begin{array}{c}\text { policy } \\
\text { document } \\
\text { preparation }\end{array}$ & $\begin{array}{c}\text { Claim } \\
\text { settlement }\end{array}$ \\
\hline \multirow[t]{2}{*}{ ICT } & Pearson Correlation & 1 & $.456^{* *}$ & $.205^{* *}$ \\
\hline & Sig. (2-tailed) & & .000 & .000 \\
\hline \multirow[t]{2}{*}{ policy document preparation } & Pearson Correlation & $.456^{* *}$ & 1 & ss \\
\hline & Sig. (2-tailed) & .000 & & .001 \\
\hline \multirow[t]{2}{*}{ Claim settlement } & Pearson Correlation & $.205^{* *}$ & $.175^{* *}$ & 1 \\
\hline & Sig. (2-tailed) & .000 & .001 & \\
\hline
\end{tabular}

Source: Author's fieldwork, 2020.

Table 5 above represents a correlation analysis that depicts the relationship between ICT and efficiency in the Nigerian insurance sector. The result indicates there is a positive and significant relationship between ICT as a re-engineering strategy and the efficiency in claim settlement and the effective and timely preparation of policy documents. The result shows that ICT as a re-engineering strategy has a $20.5 \%$ shared relationship with claim settlement, though, the relationship is weak, but, it is positive. However, hypothesis one is accepted, as the p-value (0.001) is less than 0.05., it thus implies that ICT as a re-engineering strategy positively relates to the efficiency with claim settlement in insurance firms. Further, relying on the coefficient of determination, the result indicates that ICT as a re-engineering would only influence about $4 \%$ of changes in the way insurance firms manage claim settlement. The low relationship could be because the firms also feel that efficiency in claim settlement is dependent on the honesty of the claimant. This result agrees with the findings of Apampa, and Razaq (2010) and Fadun (2013) that also found that insurance firms would improve in their ability to meet their obligation when they adopt ICT in their operations. Similarly, the result is consistent with the views of Idris, Olumoko, and Ajemunigbohun (2013) that found that ICT is foundational towards driving better performance of insurance firms in Nigeria. Further, Sarkar et al., (2013) outcomes are similar to the current study, as it was found that ICT is necessary to drive the performance of insurance firms in Nigeria.

Further, the result indicates that ICT as a re-engineering strategy relates positively to the timely preparation of policy documents. The result shows that ICT as a re-engineering strategy has a $45.6 \%$ shared relationship with the timely preparation of policy documents in insurance firms. The relationship is described as moderate given the r-value, though the relationship is positive and significant as the p-value is less than 0.05, which justified the acceptance of hypothesis two. The result also indicates that ICT as a re-engineering strategy accounts for $21 \%$ of changes in the timely preparation of policy documents in insurance firms in Nigeria. The result conforms to the findings of Kimani (2017), Angima, and Mwangi (2017) which found that ICT is vital to drive increased efficiency in firms. Similarly, Adeyemo and Soye's (2017) findings also align with the study outcome, and the study of Bazini and Madani (2015) supports the study findings that ICT is fundamental as a strategy towards advancing the insurance sector. The result is also supported by the finding from the study of Yusuf et al., (2017) that found that ICT plays a major role in the improvement of the insurance sector.

\section{Conclusions and Recommendations}

The study concluded that information and communication technology has a great role to play as a re-engineering strategy in some selected insurance companies. There is a significant relationship between ICT and the operational 
performance of the insurance companies in regards to improvement on speedy and quality services to the policyholders of the insurance companies. There is an improved fast and accurate data entry for policyholders and insurers for efficient insurance services. There is reduced human error and increased speedy decision-making and processing of recorded information. The organizations experience an increased opportunity to establish great contact with international insurers through the use of global knowledge and expertise; reducing to a large extent or eliminating the lengthy and expensive process of issuing insurance policies, thus increasing accuracy and running effective call centers.

The study advances a new perspective on measures that would help the improvement of the insurance sector in Nigeria, as the study advances the need for increased attention to strategies that would help improve the overall performance of the sector. The study concludes that claim settlement as an important aspect of the insurance sector's activities requires a new approach that addresses the generality of the activities of the insurance firms. Reengineering activities cut-across all sectors of the firm, as such, in improving the claim settlement of claimants, these firms can ensure that they advance the need for a deliberate strategic approach that supports refining of the insurance firms, thereby improving their capacity to meet the expectations of their existing and prospective clients.

The study recommends there should be a frequent update of ICT facilities regularly, to impact greatly on the quality of service delivery and efficiency. There should also be the need for regular training of insurance personnel, to improve their skills, and keep them abreast of the current innovation in the use of ICT, to ensure the industry's survival in the global market. There should be a good collaboration between the insurance administrators and regulators at all levels, to ensure that every relevant information are collated which should in one way or the other assist in contributing meaningfully to the usefulness of IT ineffective service delivery

The study focused on revealing the role of ICT as a re-engineering strategy in some selected insurance companies, from the analysis of the findings, it was concluded that ICT has been able to reduce transaction costs and thereby improving productivity and offering immediate connectivity, efficiency, transparency, and accuracy, thus proving it to be a good factor of re-engineering strategy. Given this development, managers are encouraged to further invest in ICT and develop electronic insurance and electronic marketing framework that would help improve the sector. This is because it keeps them thriving in a competitive environment and ensures appropriate provision for quality service delivery to customers and enhancement of overall performance of the organizations.

\section{References}

Africa CDC. (2020, October 7). Outbreak Brief 25: COVID-19 Pandemic - 07 July 2020. Africa CDC. https://africacdc.org/download/outbreak-brief-25-covid-19-pandemic-07-july-2020/

Akhavan, P. P. (2006). Exploring the interdependency between reengineering and information technology by developing a conceptual model.

https://www.academia.edu/10973551/Exploring_the_interdependency_between_reengineering_and_information_technology _by_developing_a_conceptual_model

Angima, K., \& Mwangi, M. (2017, May). Effects of Underwriting and Claims Management on Performance of Property and Casualty Insurance Companies in East Africa | Request PDF. ResearchGate. https://doi.org/10.19044/esj.2017.v 13n 13p358

Apampa, O., \& Olatunji, R. (2010). Evaluation of ICT Penetration in Selected Insurance Companies: The Lagos Experience. Journal of Emerging Trends in Computing and Information Sciences.

Asgarkhani, M., \& Patterson, B. (2012). Information and Business Process Re-engineering through Application of Information and Communication Technologies (ICTs). 6.

Augustine, S. Y. (2017). INFORMATION AND COMMUNICATION TECHNOLOGY (ICT), A CATALYST FOR EFFECTIVE OPERATIONS: CASE OF NIGERIAN INSURANCE COMPANIES. International Journal of Advancement in Development Studies,

https://www.academia.edu/37991989/INFORMATION_AND_COMMUNICATION_TECHNOLOGY_ICT_A_CATALYS T_FOR_EFFECTIVE_OPERATIONS_CASE_OF_NIGERIAN_INSURANCE_COMPANIES

Banham, H. (2010, December). (PDF) External Environmental Analysis For Small And Medium Enterprises (SMEs). https://www.researchgate.net/publication/293022386_External_Environmental_Analysis_For_Small_And_Medium_Enterpr ises_SMEs

Bazini, E., \& Madani, F. (2015). ICT Application in the Insurance Industry: Its Impact in Customer Relationship Management. Academic Journal of Interdisciplinary Studies. https://doi.org/10.5901/ajis.2015.v4n3s 1p307 
Broersma, H. (1997). A theoretical bapproach to Business process re-engineering in south africa. RAND AFRIKAANS UNIVERSITY. ECDC. (2020, October 9). COVID-19 situation update worldwide, as of 9 July 2020. European Centre for Disease Prevention and Control. https://www.ecdc.europa.eu/en/geographical-distribution-2019-ncov-cases

Fadun, S. (2013, October). Information and Communication Technology (ICT) and Insurance Companies Profitability in Nigeria | Journal of Accounting, Business and Management (JABM). http://journal.stiemce.ac.id/index.php/jabminternational/article/view/170

Hammer, M., \& Champy, J. (1993). Reengineering the Corporation: A Manifesto for Business Revolution. HarperBusiness.

Hammer, M., \& Stanton, S. A. (1995). The Reengineering Revolution: A handbook (Illustrated edition). HarperBusiness.

Hesson, M. (2007). Business process reengineering in UAE public sector A naturalization and residency case study. Business Process Management Journal, 13, 707-727. https://doi.org/10.1108/14637150710823174

Kimani, M. (2017). Effects of Information Communication Technology Strategy Implementation on the Customer Service Delivery in the Insurance Industry in Kenya [Thesis, United States International University - Africa].

http://erepo.usiu.ac.ke:8080/xmlui/handle/11732/3163

Mohapatra, S. (2013). Business Process Reengineering: Automation Decision Points in Process Reengineering. Springer US. https://doi.org/10.1007/978-1-4614-6067-1

Mukhopadhyay, A., Ashok, S., \& Ghosh, K. (2013). Improvement of Claim Processing Cycle Time through Lean Six Sigma Methodology, by Ashok Sarkar, Arup Ranjan Mukhopadhyay \& Sadhan Kumar Ghosh, International Journal of Lean Six Sigma, Volume 4, Number 2, pp. 171-183. International Journal of Lean Six Sigma, 4, 171-183.

Sungau, J., Ndunguru, P., \& Kimeme, J. (2013, April). (PDF) The influence of Business Process re-engineering on Service Quality: Evidence from Service Industry in Tanzania. ResearchGate.

https://www.researchgate.net/publication/243964088_The_influence_of_Business_Process_re-

engineering_on_Service_Quality_Evidence_from_Service_Industry_in_Tanzania

Susanto, H., Leu, F.-Y., Chen, C. K., Leu, F.-Y., \& Chen, C. K. (2019). The Emerging Technology of Big Data: Its Impact as a Tool for ICT Development. Apple Academic Press. https://doi.org/10.1201/9781351241250

Venkatraman, M. (1994). It-enabled business transformation: From automation to business scope redefinition. Undefined. /paper/Itenabled-business-transformation\%3A-from-automation-Venkatraman/c8a5b5fdfoda179822d15b57259cdd1cb5cf9058

Yusuf, T. O., Ajemunigbohun, S. S., \& Alli, G. N. (2017). A Critical Review of Insurance Claims Management: A Study of Selected Insurance Companies in Nigeria. SPOUDAI Journal of Economics and Business, 67(2), 69-84. https://ideas.repec.org/a/spd/journl/v67y2017i2p69-84.html

This is an Open Access article distributed under the terms of the Creative Commons Attribution Licence

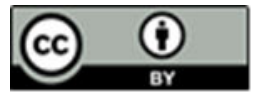

\section{Appendix - Questionnaire}

Instruction: Only staff from underwriting, claims, account, customer services marketing, and ICT Department are required to answer the questions in all sections;

Section A: Personal Data

Kindly tick $[\checkmark]$ the appropriate against each chosen answer

DOI: $10.25103 /$ ijbesar.143.06 
1. Name of Organization

2. Sex
(a) Male [ ] (b) Female[ ]

3. Age (a) 18 -30 yrs. [ ] (b) 31-40yrs [ ] (c) 41-50 yrs. [ ] (d) 50 yrs. and above [ ]

4. What is your "highest" educational qualification?

(a) WASC/SSC and below [ ] (b) NCE/OND [ ] (c)HND/B.SC [ ]

(d) MASTER DEGREE AND ABOVE [ ] (e) Others Specify

5. Kindly state your Job designation

(a) Top management (b) Middle management (c) low management

(6) What is your department?

(a) Underwriting (b) Claims (c) Marketing (d) Account (e) Other specify

\section{Section B: Research Questions}

Please indicate by ticking $[\checkmark]$ in the appropriate box, showing your level of agreement/ disagreement to each of the questions. The key is explained thus: $\mathrm{SA}=$ strongly agree; $\mathrm{A}=$ Agree; $\mathrm{UN}=\mathrm{Undecided}$; $\mathrm{D}=\mathrm{Disagree}$; and $\mathrm{SD}=$ strongly disagree.

\section{Research question 1}

What are the roles of ICT on claim settlement as a re-engineering strategy in some selected insurance companies?

\begin{tabular}{|c|c|c|c|c|c|c|}
\hline $\mathbf{S} / \mathbf{N}$ & The roles of ICT on claim settlement & $\mathbf{S A}$ & A & $\mathbf{N}$ & D & SD \\
\hline 7 & $\begin{array}{l}\text { Use of information technology tools improves claim settlement } \\
\text { related works. }\end{array}$ & & & & & \\
\hline 8 & $\begin{array}{l}\text { Deployment of IT tools has increased efficiency in database } \\
\text { management and reconciliation of claims payments }\end{array}$ & & & & & \\
\hline 9 & $\begin{array}{l}\text { The deployment of ICT has enabled operational efficiency in your } \\
\text { organization and the time for the claim settlement process has } \\
\text { been reduced substantially. }\end{array}$ & & & & & \\
\hline 9 & $\begin{array}{l}\text { The aim of working resiliently regardless of the social distancing } \\
\text { and lockdown in every part of the country was achieved, thus } \\
\text { eliminating organizational distancing. }\end{array}$ & & & & & \\
\hline 10 & $\begin{array}{l}\text { The computerized process has improved quality services, curbed } \\
\text { time-wasting in processing, shared a database, and made } \\
\text { information available at many branches at the same time. }\end{array}$ & & & & & \\
\hline
\end{tabular}

Research Question 2

What is the effect of ICT on preparation of policy documents as a re-engineering strategy in some selected insurance companies?

\begin{tabular}{|c|c|c|c|c|c|c|}
\hline $\mathbf{S} / \mathbf{N}$ & ICT on preparation of policy document & $\mathbf{S A}$ & A & $\mathbf{N}$ & $\mathbf{D}$ & SD \\
\hline 11 & $\begin{array}{l}\text { Company's advancement in technology has transformed some } \\
\text { techniques in underwriting management }\end{array}$ & & & & & \\
\hline 12 & $\begin{array}{l}\text { ICT invention and initiative has helped your organization in } \\
\text { meeting the customer's demand and increased customers' } \\
\text { satisfaction. }\end{array}$ & & & & & \\
\hline 13 & ICT tools are crucial in underwriting process. & & & & & \\
\hline 14 & $\begin{array}{l}\text { The deployment of ICT in the preparation of policy documents has } \\
\text { reduced cost and improved turnaround time }\end{array}$ & & & & & \\
\hline 15 & $\begin{array}{l}\text { During the pandemic lockdown, the use of ICT has consistently } \\
\text { improved the service delivery of your organization. }\end{array}$ & & & & & \\
\hline 16 & $\begin{array}{l}\text { During the lockdown, ICT eliminated face-to-face contact and } \\
\text { facilitated electronic insurance. }\end{array}$ & & & & & \\
\hline
\end{tabular}

